\title{
Architecture of Political Legal Communication
}

\author{
Adian Nicolescu ${ }^{1}$, Mirela Teodorescu ${ }^{2}$, Daniela Gîfu ${ }^{3, *}$ \\ ${ }^{1}$ University of Craiova, 13 A. I. Cuza Street, Craiova 200585, Romania \\ ${ }^{2}$ Independent Researcher, Craiova, Romania \\ 3 "Alexandru Ioan Cuza" University of laşi, Bd. Carol I no. 11, Iaşi 700506, Romania \\ *E-mail address: danigifu@yahoo.com
}

\begin{abstract}
Political communication has its roots to the earliest classical studies of Aristotle and Plato, modern political communication research is very much an interdisciplinary field of study, drawing on concepts from communication, political science, journalism, sociology, psychology, history, rhetoric, and other fields. In their seminal Handbook of Political Communication, Nimmo and Sanders (1981) traced the development of the field as an academic discipline in the latter half of the 20th century, and other scholars have described the breadth and scope of political communication (Kaid, 1996; Swanson \& Nimmo, 1990). There have been advanced many definitions of political communication but none has gained universal acceptance. Perhaps the best is the simplest: Chaffee's (1975) suggestion that political communication is the "role of communication in the political process". The current study intend to do a presentation of message hermeneutics, interpretation and discourse architecture customized for a political one.
\end{abstract}

Keywords: communicational act; communicational fact; political communication; political discourse

\section{INTRODUCTION}

The humanity foundation relies on solidarity. The power of social cohesion comes from the primary tendency of attachment and trust. It is inevitable to become human without passing through the corridor of the communion selection. The engine of social consistency is the influence. Related to this system of social reproduction, two inertias are defined. The centrifugal inertia of the social system is called alienation (Vlăduțescu, 2006; Borowski, 2013). This type of social connection covers the phenomenon of remaining outside the circuits of the social influence. The alienation is a frail force. The alienation network is weak and with no consolidation mechanisms. Thus the alienation appears as a system error, as a grip of the social influence gear. The centripetal inertia focuses on the concept of power. The power operators are those who know and can place themselves at the commanding nodes of the social influence. Any kind of power is an influencing power. We learn to discover ourselves, to explore ourselves, to get close to the others, to understand each other in terms of influences, in the parameters of some grids of influence (Borowski, 2014). 


\section{COMMUNICATIONAL ACT, FACT, MESSAGE}

In communication, the communicational subject organizes its meaning emission in the idea of achieving some goals. At the same time, it avoids stimulating of sets of meanings that would go against achieving the communicational target. As much it would volitional censor the communication (meaning act of communication), it is unable to completely dominate, such as "say also what not want to say" (communicational fact). The conclusion is that any communication is an event consisting in different proportions of communicational acts and facts. Any communication event, has in its structure several elements: a communicational object (a certain reality), a producer of information that detaches it from the place or and retrain it giving him new meanings, a transfer channel and a consumer that communicational exploit the whole created situation assembly and reaches up to constitute a transinformation.

In his book, Communicational and Message Theory Concepts and Notions, the professor Stefan Vladutescu from University of Craiova/Romania, developed the concepts of communicational act and fact, as well of the communicational event. These items are not new. They were used by specialists, without a rigor they would not be criticized, because it belongs partly of maturity reached by communication theory, by its critical phase. M. Heidegger showed that understanding of the world (science, generally) runs in each area a road in three steps: the step of simplistic understanding, that of "artistic" understanding and finally, the step of the critical understanding. Philosophy, would be reachead after a long evolution only simultaneous with Immanuel Kant to its critical phase ("Critique of Pure Reason," "Critique of Practical Reason", "Critique of Judgment"). "This step, asserts Stefan Vlăduţescu, have touched the communication and information theory today after "Criticism of communication" by Lucien Sfetz" (Vladutescu, 2006). These "critics" are not deconstructed steps but judicious analysis, positive of learning objects. "Criticism" so is and thus has to be understood: in the classical sense "to judge, to discern" coming from the Greek "krinein" (Vladutescu, 2009). In each communicational exercise there are information act and information fact. Information and transinformation are constituted inside of the registry of "sensitivity" of the consumer. They are determined by the force of the meanings passing the "exam" of communicational grid criteria. The problem of the communicational event arises only if it is relevant to the aims, objectives and interests that shape cognitive and articulates structural criteria for selection of grid composition. If they have not the relevant force, they are not taken into account, they are not selected as acts or facts. Relevancy is the threshold of significance.

Our contact with information sources can be determined in two ways: passive, when the emitted information by the source itself falls in our reception field, and active, when we ourselves are looking or are express coming in the way of the informative activity of a source. In both cases there is a selection grid control of the consumer depending on the approach nature (active or passive) and of the prosexis features of the meanings production of the source. The passive contact is constituted in a consumed communicational fact, and active contact, in a communicational fact. The concept of "fact", in the sense of reality that imposes itself, is a later gain of the conceptual apparatus of the information science. However, as a gesture of evolutionary coherent thinking, its definitive contents, by connotation expression , the consciousness of difference act-fact has pre-existed. By the time the experience reaches personality, becomes productive as skill. Communicative skills took over evolutionary generic communicative spirit, on the one hand, the widening field of communicative activity (new fields, new types of information act or fact type, etc.) and, on the other hand, the increase in number and the sensitivity of cognitive schemas and communicative scales, in the 
amplification area of communicative mechanisms, such as automatic attention given to the new, the unexpected, rare, the interesting and the important, and improving communication strategies for information searching. The act and fact are communicational approaches of productive gnosis practice or consuming, mentions professor Vladutescu, so there is only as event, manifest and not virtual. Information -Virtuality is itself an event, i.e. a fact. The idea that information should have a structure "built" and itself as a "construction" it is not new. It looks newer than it actually is, just by expanding the number of those who adopt (Vladutescu,2009).

Communication is constituted as assembly of facts of language that the process protagonists put in the work targeting construction or modification of a poetic or physical mood, ideas, thoughts, feelings or material-physical reality of any kind. Within the process there is a transfer of targeted message meanings: knowledge, ideas, feelings, beliefs, opinions, experiences. These aim the installation, modification or consolidation of some behaviors, attitudes, value systems, opinions or positions. Orientation is the intentional part of communication and it consists of motivations, interests, revealed or hidden motives. Depending on orientation are built the "programs" of communication instance. Communication, as an interactive construction, involves practices of thinking, knowledge and language. Within the society, there is not a separate, autotelic domain of communication and could not imagine such a field than theoretical, because ontogenetic and phylogenetic takes part of the essence of society. Communication has its impress in establishment, organization and functioning of society and of all activities that derive from them. Social interaction that gives coherence of the society requires a communicative interaction, and social facts and acts are implicitly communicative: any action based on an idea and expressing, in one way or another, by herself performing, the communicational idea from where it goes. Communication appears, from this perspective as a fundamental social process, social facts from groups, institutions and organizations to large human communities are constituted and there is by reason of communicational processes.

"The message will automatic be accompanied by additional negative messages: indifference, lack of warmth, etc. Therefore, in order to protect the true message, the productive thinking has to put it into a discourse in which to inoculate also security instructions. Putting the message in language is shaped by a cultural inertia of literature, philosophical, theological, mythological, etc. To ensure viability within a discourse, to the message should be additional messages implanted by the way of secondary codes. Insertion of language-cogitation of the message is based on safety and formatting of the formulation. Everyone who wants to be just must be exaggerated. The message is unable to transfer as message. The message always comes after. The message comes after the discourse was over" concludes professor Vladutescu. To set oneself just to write the message is a failure on the language borders movement. The language is felt to be tight when the message is great (McNair, 2011; Smarandache, Vladutescu, 2014).

\section{MESSAGE HERMENEUTICS}

Philosophy to express itself will push the boundaries of discursively: of the language and the cogitation. A solution for "unfettered" language was found in apofatism, and a solution for unleashing of cogitative (for absolute expression of the absolute) found in "Sigetik" Heidegger (in logic of silence). Logos, language meeting with cogitative, has no limits. When he talks to himself, cogitations spirit transmits him messages. Talking to others, 
thinking produces discourses. The ancients had always prepared discourses (logos) for various occasions. For us, our feelings and ideas are messages that carries their own name. The cogitative spirit transfers its spirituality in the form of discourse. It follows that discourse is inevitable, and the message only mediated approachable.

Any communication opens a hermeneutic situation whose main axis is the recognition of the other. The message is turned otherness. The message is transferring hardly: this effort of communicational modularity and inscriptioning has a motivation below. The message is an effort for the other, to recognize otherness. Message is wrapping in the discourse. The specifics of any message does not come from the language or from cogitations that they put in progress, but from the basic elements of message yearning. These structural elements are: mitem, philosophems, themes, topics, motifs, ideas, spiritual figures, semiotic configurations. That you can enter in the hermeneutical situation miracle is decisive "can listen" (Gadamer, 2001). Meeting with other rising above own limit, even where is the matter of dollars or the interests of power. Ability to listen, argues the contrary Gadamer (2001, p. 516 ), has two sides: the subjective side, consisting of actual ability to listen, and the objective side, meaning to have a common language. Compared with peers, important is his experiment of "you" as "you", in other words, do not ignore his claim and allow him to address us. This requires openness. However, "this opening does not occur, until the end, just to the one that we want to let him address us. One who is willing to listen is, rather open in principle" (Gadamer, 2001). Without such openness to others there is no genuine human connection. Comembership always means, in the same time, possible to listen to the other.

If the two understand each other, this does not mean that one he "comprehend" the other, i.e. it includes the mind. Likewise, to "listen / someone" does not mean simply that we blindly what the other wants. Such individuals are called dependent. Opening for other includes, thus, being forced to admit to myself something against me, even if there was no other who could impose it against me. The fact to not hear and to hear wrong - are the result of the same cause, which can be found in ourselves. He doesn't hear or he hears wrong the one who is listening permanent himself, whose ear is somehow so full of that address that he permanent address himself, following his instincts and interests, so that he may not hear the other. This is all possible nuances, the essential feature of all of us. The fact of becoming again and again, against this, apt for understanding, "i.e. listen to the other, it seems to be true elevation of man to the condition of humanity" (Gadamer, 2001).

In hermeneutical situation is performed a common language. Acquiring of a common language is not a tool for the preparation of communicative purposes. Performing "coincides with itself the performing of comprehension and understanding with each other" (Gadamer, 2001). From this perspective, the communication between people creates a common language in the same way that, conversely, implies (Gadamer, 2001). Alienation of people is showed in that they do not speak the same language (as it is sayed), and the approach in that is found common language. As performing of hermeneutical situation, "each dialogue requires a common language, or better said, perform a common language" (Gadamer, 2001). Is here something to put in middle to which the dialogue partners are partaked and in connection with changing points of view. Understanding on something meant to be performed in the hermeneutical situation means that, necessarily, preliminary to develop a common language. It is not an external process of adjustment of some tools, even be downright wrong to say that partners adapt to each other. Partners "arrive rather within dialogue sensed in fair way under truth work that unites in a new community" (Gadamer, 2001). Understanding is not a simply self throw into the game and an impose of own point of view, but a "metamorphosis to the common element in which we do not remain what we were" (Gadamer, 2001). 


\section{POLITICAL COMMUNICATION}

Political science belongs to social science discipline being concerned with the study of the state, nation, government, and politics and policies of government. Aristotle defined political science as the study of the state. It deals extensively with the theory and practice of politics, also the analysis of political systems, political behavior, and political culture. Political scientists "see themselves engaged in revealing the relationships underlying political events and conditions, and from these revelations they attempt to construct general principles about the way the world of politics works". Political science is interdisciplinary intersecting with many fields including economics, law, sociology, history, anthropology, public administration, public policy, national politics, international relations, comparative politics, psychology, political organization, philosophy, communication theory and political theory. Although it was codified in the 19th century, when all the social sciences were established. Political science has ancient roots originated almost 2,500 years ago with the works of Plato and Aristotle.

Political communication is a sub-field of political science and communication that interacts with the production, dissemination, procession and effects of information, both through media and interpersonally, within a political context. Also are included the study of the media, the analysis of discourses by politicians and those that are trying to influence the political process, and formal and informal conversations among members of the public, among other aspects of society. The study and practice of political communication focuses on the ways and means of expression of a political nature. Robert E. Denton and Gary C. Woodward, two important contributors to the field, in Political Communication in America characterize it as the ways and intentions of message senders to influence the political environment. This includes public discussion (e.g. political discourses, news media coverage, and ordinary citizens' talk) that considers who has authority to sanction, the allocation of public resources, who has authority to make decision, as well as social meaning like what makes someone American. In their words "the crucial factor that makes communication 'political' is not the source of a message, but its content and purpose."

Specific for political communication is the persuasive discourse. Basically for persuasion intentions it is speaking about a very stable kind of intention, persistent through all the process of elaboration and performance of a discourse, oriented to a particular type of behavior on the part of the hearers (as communicative intentions, persuasive intentions lead to a particular kind of individual social actions), namely, their persuasion in terms of the acceptance of beliefs and goals expressed by the speaker (or, at least, a significant reduction in the distance between the mental states manifested by the speaker and those of the hearers, naturally intending to lead hearers to action). Quoting Book I of Aristotle's Rhetoric: "Lastly, persuasion is produced by the speech itself, when we establish the true or apparently true from the means of persuasion applicable to each individual subject. Now, since proofs are affected by these means, it is evident that, to be able to grasp them, a man must be capable of logical reasoning, of studying characters and the virtues, and thirdly the emotions - the nature and character of each, its origin, and the manner in which it is produced. Thus it appears that Rhetoric is as it were an offshoot of Dialectic and of the science of Ethics, which may be reasonably called Politics." (Rhetoric I, 1356a15-30)

Persuasive discourse is defined by Robin Lakoff (1982) as the nonreciprocal "attempt or intention of one party to change the behavior, feelings, intentions, or viewpoint of another by 
communicative means." Advertising, propaganda, political rhetoric, and religious sermons are obvious examples of persuasive discourse; however, persuasion may also occur in conversation.

Following Cicero's classical oration and Aristotle's ethos, Hugh Rank (1988) suggests a basic persuasive formula for advertisements, political speech and other types of persuasive discourse, through five components (a) attention-getting, (b) confidence-building, (c) desirestimulating, (d) urgency-stressing, and (e) response-seeking.

In her work, "The Foundations of the Babel Tower, Daniela Gifu, shows the persuasion model (or schema enhancement / mitigation) developed by Hugh Rank, which allows persuasive agents to choose for the following four strategies: enhancing their strengths; enhancing weaknesses of the opponent; minimize vulnerabilities; minimizing the strengths of the opponent. In the same context are presented by Charles U. Larson also the tactics / methods and used in enhancing qualities of individuals and their opponents flaws (repetition, association, composition) and to minimize personal flaws and qualities of their opponents (omission, diversion, confusion ). Among the tools of persuasion are the myth, the seduction, the lie, the fiction.

\section{MYTHS USED IN POLITICAL DISCOURSE}

In his "Myths and political mythologies" Raoul G. Prardet identifies four fundamental myths "that any political discourse, in any geographical and historical area can have, because there is a high mobilizing capacity of the myth, born of a fractured political reality: product of social reality and social reality producer". Political upheavals of the last two centuries of European history have been accompanied by a stunning mythological effervescence: the denunciation of evil conspiracy tending to crush peoples of obscure forces and perverse domination; image of a lost golden age, whose happiness is due to a retrieval or a saving Revolution would allow humanity to enter the last phase of its history and would ensure forever the reign of justice; call the lord savior, restorer of order or producer of a wide variety of collective. Claude Levi-Strauss discern that the elements that builds the story are grouped in the same series, are structured into permanent associations. The myth of the Savior, the providential leader always appears associated to symbols of purification: the hero who saves, the releaser one, crushes evil. It is always associated with light - gold, the sun rising in the sky brightness gaze - and verticality - sword, scepter, secular tree, mountain. Also, the reason of maleficent conspiracy will always put in relation to a soloist of dirt - is associated repugnant animals, crawling, creeping, disseminates poison.

Conspiracy. Mythology of the plot has in its center the frightening image of the organization. Its master feature is the secret. Accomplices are bound by a vow of silence and a dire punishment will hit them if they betray. Whatever the name, the nature or purpose of conspiracy it is part of a psychological and social climate of insecurity, fear, anguish. An undeniable specialty and almost exclusively of the political discourse specific crisis of any kind is diversion. The mechanism is easy to play, but its implementation in application requires involving many factors. It builds a comprehensive discourse, aggressive incriminating against someone; this discourse (of the rule do-not-know-whom) is taken and amplified by most of the media, being born pro or against. trends .

The Savior. The emphasis is on individual mediocrity and his destiny - it is mediocre by birthplace, the social environment to which he belongs, mediocre by his private life believes R. Gitardet. R. G. Schwarzenberg asserts that in this case "simplicity is not only 
deliberate, it becomes blatantly". The crowds are so motivated, even obliged to identify with him. The mechanism for identifying individual destiny with collective destiny is the principle that dominates political discourse of the Savior. He has authority, Max Weber identified three types of authority and legitimacy. Traditional authority is based on usage and custom, as that of senior or hereditary monarch. Legal-rational authority, based on the institutions, on a statute, is that of the governor in a modern state. We have not conformed to the person but to the position that Constitution invested. Finally, there is the charismatic authority of the Savior, the Prophet and even demagogic. There is a time of waiting and of calling - a time that is formed and spreads the image of a Savior - then a time of presence of the Savior, that ultimately the remembering time, in which his figure, projected in the past will be changed according to "whims" of the memory, with its selective mechanisms, with discharges and his exaggeration.

Golden Age. Is the persistence of a rhythm of life, protecting privacy of a closed social group, jointly strictly hierarchical. Are visions of a present and a past defined by what they were or what they considered to be. The periodicity (more or less accurate) four years - during election campaigns - returns in political discourse periods of glory invocation, a kind of "good old times" of cultural openness, of civilization, of democracy, civic responsibility.

Unity. "Everything divided tends to unify" (cited. J. de Maistre). Nature truly noble of man confuses the permanent effort to impose a single will and orderly. We can talk of the existence of such a unit (NATO, EU) to which some aspire, convinced of benefits, while others stubbornly keep aside their strong individuality allowing this. Based on these two trends exist, of course, the two types of political discourse: one centered on the need for unity argument, another emphasizes the disadvantages of accession to these organizations.

\section{PERSUASION TECHNIQUES THAT ESTABLISH TRUST}

Plain Folks. This technique gains trust and credibility by making the messenger appear to be just like the audience. Candidates may paint themselves as a working mom, or a family man. By putting themselves on the level of the working class people, they give the impression that they understand and relate to the problems and issues important to those constituents.

Sentimentality. An extension of the plain folks technique, sentimentality paints a picture of the candidate in a warm, happy family relationship. Photos of the candidates with their children, all smiling and happy, are an example of this technique. Stories about the candidates' dogs also work on sentimentality.

Charisma. Charisma is a quality that draws people to another person. It includes charm, flattery, confidence, and strength, all in one package. The social theorist Max Weber first introduced the idea of charismatic leadership over 100 years ago. According to a study done by Alex Todorov of Princeton University, people tend to choose leaders that are charismatic and photogenic.

\section{EXAMPLES OF CELEBRE DISCOURSES}

A. John F. Kennedy, "Inauguration Address", January 20, 1961; Washington, D.C. "Can we forge against these enemies a grand and global alliance, North and South, East and West, that can assure a more fruitful life for all mankind? Will you join in that historic effort? 
In the long history of the world, only a few generations have been granted the role of defending freedom in its hour of maximum danger. I do not shrink from this responsibility - I welcome it. I do not believe that any of us would exchange places with any other people or any other generation. The energy, the faith, the devotion which we bring to this endeavor will light our country and all who serve it - and the glow from that fire can truly light the world. And so, my fellow Americans: ask not what your country can do for you - ask what you can do for your country.

My fellow citizens of the world: ask not what America will do for you, but what together we can do for the freedom of man".

B. Dr. Henry Kissinger has written an article entitled, "Henry Kissinger on the Assembly of a New World Order" posted at The Wall Street Journal on $29^{\text {th }}$ of August 2014.

It's an important article written by an important man. Dr. Kissinger, the Journal tells us, "served as national security adviser and secretary of state under Presidents Nixon and Ford". And his article is "adapted from his book 'World Order' " - apparently set for a September 9th unveiling from publisher Penguin Press.

The concept that has underpinned the modern geopolitical era is in crisis.

"This effort to establish world order has in many ways come to fruition. A plethora of independent sovereign states govern most of the world's territory. The spread of democracy and participatory governance has become a shared aspiration if not a universal reality; global communications and financial networks operate in real time.

The years from perhaps 1948 to the turn of the century marked a brief moment in human history when one could speak of an incipient global world order composed of an amalgam of American idealism and traditional European concepts of statehood and balance of power. But vast regions of the world have never shared and only acquiesced in the Western concept of order. These reservations are now becoming explicit, for example, in the Ukraine crisis and the South China Sea. The order established and proclaimed by the West stands at a turning point"”.

\section{CONCLUSIONS}

In the 2000 election, almost every political candidate running for office at every level (presidential, state, county, city, and local) had an active Web site. This fact indicates the current importance of Internet-related communication technologies in political communication and suggests how this specialty field has evolved since its beginnings earlier in the past century in the hands of Walter Lippman, Harold Lasswell, Paul F. Lazarsfeld, and other forefathers and founders of communication study. Despite the growth of television in the 1950s and the Internet in the 1990s, which altered the channels of communication carrying political messages to the public, certain human communication processes involved in changing political behavior have remained much the same.

\section{ACKNOWLEDGMENT}

In order to perform this research the first author received financial support from the Erasmus Mundus Action 2 EMERGE Project (2011 - 2576 / 001 - 001 - EMA2). I am also grateful to the NLP-Group@UAIC-FII for offering me support in using some tools for automatic interpretation of Romanian language. 


\section{References}

[1] S. H. Chaffee (Ed.) (1975). Political communication. Beverly Hills, CA: Sage Publications.

[2] L. L. Kaid (1996). Political communication. In M. Salwen \& D. W. Stacks (Eds.), An integrated approachto communication theory and research (pp. 443-457). Hillsdale, NJ: Lawrence Erlbaum.

[3] Andrzej Borowski, International Letters of Social and Humanistic Sciences 14 (2014) $33-41$.

[4] Ştefan Vlăduţescu, American International Journal of Contemporary Research 3(10) (2013).

[5] G. Rajović, J. Bulatović, International Letters of Social and Humanistic Sciences 6 (2013) 24-35.

[6] C. R. Berger, M. E. Roloff, D. R. Ewoldsen (Eds.). (2009). The handbook of communication science. Sage publications.

[7] Andrzej Borowski, International Letters of Social and Humanistic Sciences 14 (2014) 7-17.

[8] S. W. Littlejohn, K. A. Foss (2010). Theories of human communication. Waveland Press.

[9] Newman, B. (Ed.). (1999). The handbook of political marketing. Thousand Oaks, CA: Sage.

[10] Florentin Smarandache, Ştefan Vlăduţescu (2014). Communication Neutrosophic Routes. Columbus, OH: Educational Publishing.

[11] Colhon M. (2013). Automatic Lexical Alignment between Syntactically Weak Related Languages. Application for English and Romanian. In Computational Collective Intelligence. Technologies and Applications (pp. 266-275). Springer Berlin Heidelberg.

[12] Janusz Grabara, Michal Kolcun, Sebastian Kot, International Journal of Education and Research 2(2) (2014).

[13] Ştefan Vlăduţescu, Journal of Studies in Social Sciences 8(2) (2014).

[14] Nimmo, D., \& Sanders, K. R. (Eds.), (1981). Handbook of political communication. Beverly Hills, CA: Sage.

[15] Daniela Gifu (2013). Temeliile Turnului Babel. Bucuresti: Editura Academiei Romane.

[16] H.-G. Gadamer (2001). Adevăr şi metodă. Bucureşti: Editura Teora.

[17] Max G. Craig, Journal of Studies in Social Sciences 8(1) (2014).

[18] Ştefan Vlăduţescu, European Scientific Journal 9(32) (2013).

[19] M. G. Mangra, E. A. Cotoc, A. Traistaru (2013). Sustainable Economic Development Through Environmental Management Systems Implementation. Journal.

[20] Florentin Smarandache, Ștefan Vlăduțescu (2014). Towards a Practical Communication Intervention. Revista de Cercetare si Interventie Sociala. 
[21] Aurelia Traistaru (2013). Consolidation of the green marketing profile in current austerity period. Jokull.

[22] J. H. Gasderell, International Letters of Social and Humanistic Science 22 (2014) 85-91.

[23] Ștefan Vlăduțescu, International Letters of Social and Humanistic Sciences 23 (2014) 71-80.

[24] Tomáš Hes, Alena Neradová, Karel Srnec, International Letters of Social and Humanistic Sciences 7 (2013) 55-75.

[25] Swanson, D. L., \& Nimmo, D. (Eds.). (1990). New directions in political communication: A source book. Newbury Park, CA: Sage.

[26] Oprea-Valentin Buşu, Mirela Teodorescu, Daniela Gîfu, International Letters of Social and Humanistic Sciences 27 (2014) 82-93.

[27] Ștefan Vlăduțescu (2013). Principle of the Irrepressible Emergence of the Message. Jokull.

[28] Paula Bajdor, Iwona Grabara, I. (2014). The Role of Information System Flows in Fulfilling Customers' Individual Orders. Journal of Studies.

[29] Ștefan Vlăduțescu, International Letters of Social and Humanistic Sciences 10 (2014) 100-106.

[30] Smarandache, F. (1991). Only problems, not solutions!. Infinite Study.

[31] Smarandache, F., \& Dezert, J. (Eds.). (2006). Advances and Applications of DSmT for Information Fusion (Collected works), second volume: Collected Works (Vol. 2). Infinite Study.

[32] Mirela Teodorescu, Alina Tenescu, Communications in Applied Sciences 2(1) (2014).

[33] Andrezj Borowski, International Letters of Social and Humanistic Sciences 2 (2014) 110-121.

[34] Mirela Teodorescu, Ioan Constantin Dima, Daniela Gifu, International Letters of Social and Humanistic Sciences 20 (2014) 46-55.

[35] Ștefan Vlăduțescu, International Letters of Social and Humanistic Sciences 7 (2014) 8-13.

[36] Sebastian Kot, Janusz Grabara, Michal. Kolcun, International Letters of Social and Humanistic Sciences 15 (2014) 1-6.

[37] Andrzej Borowski, International Letters of Social and Humanistic Sciences 3 (2013) 46-53.

[38] Jason L. Powell, International Letters of Social and Humanistic Sciences 17(1) (2014) $1-60$.

[39] Jason L. Powell, International Letters of Social and Humanistic Sciences 7 (2014) 22-30.

[40] Mirela Teodorescu, Vladimir Modrak, Daniela Gîfu, International Letters of Social and Humanistic Sciences 24 (2014) 56-65.

[41] Ștefan Vlăduțescu, International Letters of Social and Humanistic Sciences 15(2) (2014) 164-170. 
[42] D. Gîfu (2007). Utilization of technology for linguistic processing in an electoral context: Method LIWC-2007. Proceedings of the Communication, Context, Interdisciplinary Congress, Vol. 1, 87-98.

[43] Mirela Teodorescu, Jozef Novak-Marcincin, Daniela Gîfu, International Letters of Social and Humanistic Sciences 27 (2014) 22-33.

[44] Ioan Constantin Dima, Ştefan Vlăduţescu (2012). Persuasion elements used in logistical negotiation: Persuasive logistical negotiation. Saarbrucken: LAP Lambert Academic Publishing.

[45] Sorin Mihai Radu, International Letters of Social and Humanistic Sciences 16 (2014) 184-193.

[46] D. W. Stacks, M. B. Salwen (Eds.). (2014). An integrated approach to communication theory and research. Routledge.

[47] Maria Nowicka-Skowron, Sorin Mihai Radu (2014). The information and company's innovative-creative activity under the current conditions of the market economy. Communication Neutrosophic Routes.

[48] Ştefan Vlăduţescu, International Letters of Social and Humanistic Sciences 25 (2014) 16-24.

[49] B. McNair (2011). An introduction to political communication. Taylor \& Francis.

[50] C. E. Ciovica, F. Cristian, V.-A. Enăchescu (2011). Communication and conflict-an intercultural approach. Euromentor Journal-Studies about education.

[51] M. Drămnescu (2014). Argumentation for social instruction model from the perspective of social innovation. eLearning \& Software for Education.

[52] J. Shopovski, F. Bezzina, M. M. Zammit, European Scientific Journal 9(7) (2013).

[53] V. A. Enăchescu, C. Damasaru, Revista de Management Comparat Internaţional/ Review of International Comparative Management 14(4) (2013) 644-653.

[54] Ştefan Vlăduţescu, International Letters of Social and Humanistic Sciences 29 (2014) 41-47.

[55] Jason L. Powell, International Letters of Social and Humanistic Sciences 16(2) (2014) 132-143.

[56] Mirela Teodorescu, Dan Ionescu, International Letters of Social and Humanistic Sciences 27 (2014) 94-99.

[57] G. Rajović, J. Bulatović, International Letters of Social and Humanistic Sciences 6 (2013) 24-35. 